\title{
MICROBIOLOGICAL INDOOR AIR QUALITY IN FACULTY'S ROOMS: RISKS ON STUDENTS' HEALTH
}

\author{
Olgica D. Stefanović*, Jelena D. Radosavljević, Marijana M. Kosanić \\ University of Kragujevac, Faculty of Science, Department of Biology and Ecology, \\ Radoja Domanovića 12, 34000 Kragujevac, Serbia \\ *Corresponding author; E-mail: olgica.stefanovic@pmf.kg.ac.rs
}

(Received February 2, 2021; Accepted April 4, 2021)

\begin{abstract}
This study deals with a quantitative and qualitative analyze of indoor airborne microbiota and estimation of microbiological quality of indoor air in faculty's rooms during the summer semester of 2017/18 school year. The concentration of bacteria was significantly higher than the concentration of fungi. The species that belong to human skin microbiota or of environmental origin were identified. According to indoor air quality breakpoints, low to medium/high level of bacterial and fungal air contaminations was noticed.
\end{abstract}

Keywords: air pollution, air quality, environmental monitoring, public health.

\section{INTRODUCTION}

Indoor air constantly contains a certain concentration of microorganisms. In the air, the microorganisms (bacteria, archaea, fungi, protists, and algae) as well as viruses, commonly exist alone or adsorbed on dust particles or saliva/water droplets forming bioaerosols. Microorganisms' concentration depends on several factors such as: temperature and relative air humidity, the number of occupants and their activities in rooms, hygiene condition, and ventilation, even on the size of the bioaerosols and the speed of sedimentation (HAAS et al., 2013).

The most of microorganisms present in the indoor air do not cause adverse health effects. However, some airborne fungi, bacteria, as well as viruses are recognized as the causative agents of allergies, asthma, and infections (WANNER and GRAVESEN, 1993; DOUWES et al., 2003; HEEDERIK and VON MUTIUS, 2012). Health risks appear when the concentrations of these infectious agents become very high. It is established that some viable bioaerosols cause infectious human diseases, such as tuberculosis, Legionnaire's disease and various forms of bacterial and viral pneumonia, influenza, measles, and gastrointestinal illness (BOUILLARD et al., 2005; TSAI and MASHER, 2005). In addition, endotoxin, a component of the outer membrane of Gram-negative bacteria, has been associated with asthma severity (BOUILLARD et al., 2005). On the other side, molds produce antigenic proteins that may cause an allergic reaction in sensitized people, including asthma, rhinitis, and conjunctivitis 
(JAAKKOLA et al., 2010; KARVALA et al., 2010). Opportunistic infections caused by some molds are generally limited to people with immunosuppressed immune system. Moreover, molds produce volatile organic compounds that cause the "musty" smell and can be irritating to the human mucous membranes (Nevalainen, 2015). World Health Organization (WHO) guidelines for indoor air quality: dampness and mold (WHO, 2009) has recognized connection between poor indoor air quality and certain health problems (irritation of mucous membranes, skin and eyes, fatigue, headache, malaise, lethargy, difficulty concentrating, sensitivity to odors and flu-like symptoms). These symptoms are known as Sick Building Syndrome (SBS). The causative agent has not been identified, moreover, the cumulative effects of numerous factors (presence of microorganisms and their metabolites, volatile organic compounds, humidity) and their excess level in the air have affected human health.

Microbiological air quality is an important criterion that must be considered when indoor workplaces are designed to provide a safe environment. Air quality of indoor environments is one of the main factors affecting health, well-being, and productivity of people. The indoor air quality depends on variety physical, chemical, and microbiological parameters (BASINंSKA et al., 2019). Recent studies have shown that there is an increase in a number of allergic reactions to microbial spores in young people (WHO, 2009; BRĄGOSZEWSKA et al., 2018) as well as potential risks of infections and contaminations. Analysis of indoor airborne microbiota represents an important parameter in characterizing specific environments, identifying possible biological risks, and acquiring information for prevention of health hazard. Therefore, there is need for regular monitoring of indoor air quality.

Monitoring data on microbiological quality of indoor air of educational buildings (faculties) in Serbia are unreachable. Students spend much of their working time indoors so poor indoor air could affect their health. Therefore, the aim of this study was to quantitative and qualitative analyze airborne microbiota and estimate the microbiological quality of indoor air in faculty's rooms.

\section{MATERIALS AND METHODS}

\section{Sampling}

Sampling area included four faculty's rooms with natural ventilation at the Faculty of Science, University of Kragujevac, Serbia, as follows: 1. Lecture room A-I-1 (surface area of $117.5 \mathrm{~m}^{2}$ ), 2. Lecture room A-I-28 (surface area of $54.8 \mathrm{~m}^{2}$ ), 3. Student laboratory A-II-2 (surface area of $48 \mathrm{~m}^{2}$ ) and Reading room A-0-1 (surface area of $55.6 \mathrm{~m}^{2}$ ). Sampling was carried out during the summer semester of 2017/18 school year, from March to May, once a week, including two sampling period, in the morning (9 a. m.) and in the afternoon (4 p. m.).

\section{Determination of the total number of bacteria and fungi}

The total number of mesophilic aerobic bacteria and fungi was determined by passive air sampling technique - the settle plate method using $9 \mathrm{~cm}$-diameter Petri dishes. Bacteria and viable fungal propagules were collected on Nutrient agar (Torlak, Serbia) with amphotericin B (Sigma-Aldrich, USA) and Sabouraud dextrose agar (Torlak, Serbia) with amoxicillin (Sigma-Aldrich, USA), respectively. Three sampling points were set in each sampling room. The Petri dishes were placed on the center of the studied rooms at a height of about $1 \mathrm{~m}$ above the floor. The sampling time was 30 minutes. After exposure, the samples were incubated at $25{ }^{\circ} \mathrm{C}$ for 7 days. Colony forming units $(\mathrm{cfu}) / \mathrm{m}^{3}$ were estimated by the Omeliansky formula (BORREGO et al., 2010) (1): 


$$
N=5 \times 10000 \times a /(p \times t)
$$

where $\mathrm{N}=\mathrm{cfu} / \mathrm{m}^{3}$ of indoor air; $\mathrm{a}=$ number of colonies per Petri dish; $\mathrm{p}=$ Petri dish surface $\left(\mathrm{cm}^{2}\right) ; \mathrm{t}=$ exposure time $(\min )$.

\section{Determination of the index of microbial air contamination}

The index of microbiological air contamination (IMA) was determined as described (PASQuARella et al., 2000). A Petri dishes, $9 \mathrm{~cm}$ in diameter, containing Nutrient agar (Torlak, Serbia) were exposed to air according to the 1/1/1 scheme (for $1 \mathrm{~h}, 1 \mathrm{~m}$ from the floor, at least $1 \mathrm{~m}$ away from walls or any relevant physical obstacle). After $48 \mathrm{~h}$ incubation at $37{ }^{\circ} \mathrm{C}$ for the isolation of human pathogenic bacteria, the grown colonies were counted. The number of colonies was the IMA. Five classes of IMA were devised: 0-5 very good; 6-25 good; 26-50 fair; 51-75 poor; >76 very poor quality of air. The values of IMA were established related to different infection or contamination risks.

\section{Identification of isolates of bacteria and fungi}

After the sampling and determination of the total number of bacteria and fungi, every morphological different colony of bacteria or fungi were re-inoculated on a nutrient medium (Nutrient agar for bacteria and Sabouraud dextrose agar for fungi). The established collection of isolates was maintained at $4^{\circ} \mathrm{C}$ until the time of identification. Bacterial isolates were characterized by microscopic examination and identified further by biochemical tests (HOLT et al., 1994). The fungal isolates were identified by colonial appearance, microscopic examination of the spore and hyphal characteristics (BARNETT and HUNTER, 1998).

\section{Statistical analysis}

Statistical analysis was conducted using SPSS 20.0 software. Student's $t$-test was used to test the significance between two groups. One-way analysis of variance (ANOVA) was used to test the significance among different groups. $\mathrm{P}<0.05$ was considered to indicate statistically significant differences.

\section{RESULTS AND DISCUSSION METHODS}

\section{Total number of bacteria and fungi}

The total number of bacteria, the total number of fungi and IMA indices are shown in Tables 1-6. The parameters were monitored during the summer semester, once a week, in the morning and in the afternoon. Passive sampling of airborne microorganisms by the settle plate method provides a valid health risk assessment as it detects larger bioaerosols which under the effect of gravity falls onto a critical surface, such as a working area in breathing zone (NAPOLI et al., 2012).

The total number of mesophilic aerobic bacteria, for all research period, was from 26 to $2117 \mathrm{cfu} / \mathrm{m}^{3}$ while the total number of fungi was from 21 to $749 \mathrm{cfu} / \mathrm{m}^{3}$. The concentration of bacteria was significantly higher than the concentration of fungi $(\mathrm{P}=0.0005)$. The statistically significant difference in the total number of bacteria and fungi between sampling months (March-May) was notice $(\mathrm{P}=0.0005)$. It was observed that the concentration of bacteria and fungi was in increase level. The concentration of bacteria was significantly higher in April and May than in March while the concentration of fungi was constantly increased. On the other side, the total number of bacteria and fungi in the morning was not significantly differed than in the afternoon $(\mathrm{P}>0.05)$. Furthermore, the concentration of 
microorganisms was not statistically significant influenced by the surface area of sampling rooms and the number of students.

In March, the total number of mesophilic aerobic bacteria was in the range from 35 to $828 \mathrm{cfu} / \mathrm{m}^{3}$, while the number of fungi was from 21 to $201 \mathrm{cfu} / \mathrm{m}^{3}$ (Tab. 1). The number of microorganisms varied during the month of March depending on activities at Faculty. The second week of March was the exam week (no lectures), which is clearly affected the number of microorganisms in lecture rooms, it was the lowest or not detected. In this period, the highest number of bacteria was noticed in the reading room. When the lectures were continuing, in the last two weeks of March, the number of bacteria and fungi was noticeably increased. The IMA indicated a low to moderate level of contamination (very good-fair air quality) (Tab. 2).

Table 1. The total number of bacteria/fungi $\left(\mathrm{cfu} / \mathrm{m}^{3}\right)$ in indoor air in faculty's room during the month of March.

\begin{tabular}{|c|c|c|c|c|c|c|c|c|c|}
\hline \multirow{3}{*}{ Room } & & \multicolumn{8}{|c|}{ Sampling period } \\
\hline & & \multicolumn{2}{|c|}{ 1. week } & \multicolumn{2}{|c|}{ 2. week } & \multicolumn{2}{|c|}{ 3. week } & \multicolumn{2}{|c|}{ 4. week } \\
\hline & & a.m. & p.m. & a.m. & p.m. & a.m. & p.m. & a.m. & p.m. \\
\hline \multirow{2}{*}{ A-I-1 } & bacteria & 42 & 47 & 116 & - & 233 & 106 & 289 & 88 \\
\hline & fungi & 35 & 33 & - & - & 153 & 169 & 167 & 35 \\
\hline \multirow{2}{*}{ A-I-28 } & bacteria & 42 & 42 & 42 & - & 106 & 276 & 124 & 70 \\
\hline & fungi & - & 23 & 21 & - & 63 & 201 & 124 & 61 \\
\hline \multirow{2}{*}{ A-II-2 } & bacteria & 84 & 63 & 116 & - & 201 & 254 & 376 & 105 \\
\hline & fungi & - & 82 & 42 & - & 138 & 127 & 49 & 74 \\
\hline \multirow{2}{*}{ A-0-1 } & bacteria & 35 & 48 & 828 & - & 55 & 191 & 270 & 366 \\
\hline & fungi & - & 21 & 42 & - & 76 & 118 & 148 & 54 \\
\hline
\end{tabular}

- not detected.

Table 2. The index of microbiological air contamination during the month of March.

\begin{tabular}{|c|c|c|c|c|c|c|c|c|}
\hline \multirow[b]{3}{*}{ Room } & \multicolumn{8}{|c|}{ Sampling period } \\
\hline & \multicolumn{2}{|c|}{ 1. week } & \multicolumn{2}{|c|}{ 2. week } & \multicolumn{2}{|c|}{ 3. week } & \multicolumn{2}{|c|}{ 4. week } \\
\hline & $\begin{array}{c}\text { № of } \\
\text { colonies }\end{array}$ & Level & $\begin{array}{c}\text { № of } \\
\text { colonies }\end{array}$ & Level & $\begin{array}{c}\text { № of } \\
\text { colonies }\end{array}$ & Level & $\begin{array}{c}\text { № of } \\
\text { colonies }\end{array}$ & Level \\
\hline A-I-1 & 14 & good & - & - & 3 & $\begin{array}{l}\text { very } \\
\text { good }\end{array}$ & 3 & very good \\
\hline A-I-28 & 17 & good & 2 & $\begin{array}{l}\text { very } \\
\text { good }\end{array}$ & 9 & good & 28 & fair \\
\hline A-II-2 & 44 & fair & 2 & $\begin{array}{l}\text { very } \\
\text { good }\end{array}$ & 22 & good & 4 & very good \\
\hline A-0-1 & 23 & good & 20 & good & 25 & good & 11 & good \\
\hline
\end{tabular}

- not detected.

In April, the total number of mesophilic aerobic bacteria was in the range from 82 to $2117 \mathrm{cfu} / \mathrm{m}^{3}$, while the number of fungi was from 47 to $476 \mathrm{cfu} / \mathrm{m}^{3}$ (Tab. 3). The number of microorganisms during the month of April was in increase, and the number of bacteria was greater than fungi. The highest concentration was observed in the first and the second week of sampling. Regular teaching process, students attending lectures obviously contributed to the increased number of microorganisms. According to the IMA a low to medium degree of contamination was noticed (Tab. 4). 
Table 3. The total number of bacteria/fungi $\left(\mathrm{cfu} / \mathrm{m}^{3}\right)$ in indoor air in faculty's room during the month of April.

\begin{tabular}{|c|c|c|c|c|c|c|c|c|c|}
\hline \multirow{3}{*}{ Room } & & \multicolumn{8}{|c|}{ Sampling period } \\
\hline & & \multicolumn{2}{|c|}{ 1. week } & \multicolumn{2}{|c|}{ 2. week } & \multicolumn{2}{|c|}{ 3. week } & \multicolumn{2}{|c|}{ 4. week } \\
\hline & & a.m. & p.m. & a.m. & p.m. & a.m. & p.m. & a.m. & p.m. \\
\hline \multirow{2}{*}{ A-I-1 } & bacteria & 446 & 662 & 258 & 2117 & 247 & 690 & 482 & - \\
\hline & fungi & 241 & 155 & 99 & 476 & 203 & 52 & 64 & - \\
\hline \multirow{2}{*}{ A-I-28 } & bacteria & 812 & 775 & 2062 & 368 & 146 & 258 & 319 & 258 \\
\hline & fungi & 330 & 199 & 250 & 188 & 148 & 104 & 78 & 68 \\
\hline \multirow{2}{*}{ A-II-2 } & bacteria & 310 & 164 & 94 & 893 & 174 & 141 & 352 & 82 \\
\hline & fungi & 58 & 117 & 47 & 209 & - & - & 70 & 78 \\
\hline \multirow{2}{*}{ A-0-1 } & bacteria & 487 & 723 & 509 & 265 & 188 & 282 & 470 & 941 \\
\hline & fungi & 202 & 68 & 358 & 191 & 117 & 54 & 120 & 148 \\
\hline
\end{tabular}

- not detected.

Table 4. The index of microbiological air contamination during the month of April.

\begin{tabular}{lcccccccc}
\hline & \multicolumn{8}{c}{ Sampling period } \\
\cline { 2 - 8 } Room & \multicolumn{2}{c}{ 1. week } & \multicolumn{2}{c}{ 2. week } & \multicolumn{2}{c}{ 3. week } & \multicolumn{2}{c}{ 4. week } \\
\cline { 2 - 8 } & $\begin{array}{c}\text { No of } \\
\text { colonies }\end{array}$ & Level & $\begin{array}{c}\text { No of } \\
\text { colonies }\end{array}$ & Level & $\begin{array}{c}\text { No of } \\
\text { colonies }\end{array}$ & Level & $\begin{array}{c}\text { No of } \\
\text { colonies }\end{array}$ & Level \\
\hline A-I-1 & 39 & fair & 10 & good & 9 & good & - & - \\
A-I-28 & 14 & good & 1 & $\begin{array}{c}\text { very } \\
\text { good }\end{array}$ & 5 & $\begin{array}{c}\text { very } \\
\text { good }\end{array}$ & 2 & $\begin{array}{c}\text { very } \\
\text { good }\end{array}$ \\
A-II-2 & 3 & $\begin{array}{c}\text { very } \\
\text { good }\end{array}$ & 34 & fair & 8 & good & 1 & $\begin{array}{c}\text { very } \\
\text { good }\end{array}$ \\
A-0-1 & 11 & good & 14 & good & 12 & good & 22 & good \\
\hline
\end{tabular}

- not detected.

In May, the total number of mesophilic aerobic bacteria was in the range from 26 to $838 \mathrm{cfu} / \mathrm{m}^{3}$, while the number of fungi was from 60 to $749 \mathrm{cfu} / \mathrm{m}^{3}$ (Tab. 5). The concentration of fungi during the month of May was in increase probably due to warmer weather, prolonged natural ventilation and thus greater contact with the outside air. It is known that the number of fungi indoors is depended on the number and diversity of "outdoors" fungi. The IMA demonstrated a low level of contamination (Tab. 6).

Literature search aimed on microbiological indoor air quality of faculties' rooms have showed similar results. Other researchers have noticed a higher number of bacteria than fungi. GUAN et al. (2015) in the reading rooms of faculty in China determined the total number of bacteria between 209 and $838 \mathrm{cfu} / \mathrm{m}^{3}$. The total number of bacteria and fungi in the reading rooms at the University of Ethiopia was between 367 and $2595 \mathrm{cfu} / \mathrm{m}^{3}$ and 524 and 1992 $\mathrm{cfu} / \mathrm{m}^{3}$, respectively (HAYLEEYESUS and MANAYE, 2014). The highest total mean bacterial load was $2826.35 \mathrm{cfu} / \mathrm{m}^{3}$ in the morning and $4514.63 \mathrm{cfu} / \mathrm{m}^{3}$ in the afternoon in classrooms of primary schools determined by settle plate method (ANDUALEM et al., 2019). Two-years research (STRYJAKOWSKA-SEKULSKA et al., 2007) was carried out at the University in Poland. During the first year, the number of bacteria was 120 to $2300 \mathrm{cfu} / \mathrm{m}^{3}$ and fungi from 130 to $1100 \mathrm{cfu} / \mathrm{m}^{3}$. During the second year, the number of bacteria was 110 to $3300 \mathrm{cfu} / \mathrm{m}^{3}$, while the number of fungi was 90 to $800 \mathrm{cfu} / \mathrm{m}^{3}$. 
Table 5. The total number of bacteria/fungi $\left(\mathrm{cfu} / \mathrm{m}^{3}\right)$ in indoor air in faculty's room during the month of May.

\begin{tabular}{|c|c|c|c|c|c|c|c|c|c|}
\hline \multirow{3}{*}{ Room } & & \multicolumn{8}{|c|}{ Sampling period } \\
\hline & & \multicolumn{2}{|c|}{ 1. week } & \multicolumn{2}{|c|}{ 2. week } & \multicolumn{2}{|c|}{ 3. week } & \multicolumn{2}{|c|}{ 4. week } \\
\hline & & a.m. & p.m. & a.m. & p.m. & a.m. & p.m. & a.m. & p.m. \\
\hline \multirow{2}{*}{ A-I-1 } & bacteria & 304 & 146 & 173 & 112 & 52 & 363 & 550 & 68 \\
\hline & fungi & 279 & 268 & 439 & 749 & 163 & 131 & 334 & 170 \\
\hline \multirow{2}{*}{ A-I-28 } & bacteria & 225 & 104 & 146 & 269 & 183 & 26 & 802 & 262 \\
\hline & fungi & 356 & 146 & 289 & 165 & 356 & 111 & 348 & 243 \\
\hline \multirow{2}{*}{ A-II-2 } & bacteria & 235 & 799 & 323 & 149 & 183 & 52 & 550 & 537 \\
\hline & fungi & 111 & 183 & 222 & 211 & 196 & 104 & 483 & 484 \\
\hline \multirow{2}{*}{ A-0-1 } & bacteria & 373 & 437 & 138 & 173 & 94 & 68 & 838 & 225 \\
\hline & fungi & 343 & 277 & 340 & 374 & 199 & 60 & 138 & 235 \\
\hline
\end{tabular}

Table 6. The index of microbiological air contamination during the month of May.

\begin{tabular}{|c|c|c|c|c|c|c|c|c|}
\hline \multirow[b]{3}{*}{ Room } & \multicolumn{8}{|c|}{ Sampling period } \\
\hline & \multicolumn{2}{|c|}{ 1. week } & \multicolumn{2}{|c|}{ 2. week } & \multicolumn{2}{|c|}{ 3. week } & \multicolumn{2}{|c|}{ 4. week } \\
\hline & $\begin{array}{c}\text { № of } \\
\text { colonies }\end{array}$ & Level & $\begin{array}{c}\text { № of } \\
\text { colonies }\end{array}$ & Level & $\begin{array}{c}\text { № of } \\
\text { colonies }\end{array}$ & Level & $\begin{array}{c}\text { № of } \\
\text { colonies }\end{array}$ & Level \\
\hline A-I-1 & 1 & $\begin{array}{l}\text { very } \\
\text { good }\end{array}$ & - & - & 1 & $\begin{array}{l}\text { very } \\
\text { good }\end{array}$ & 3 & $\begin{array}{l}\text { very } \\
\text { good }\end{array}$ \\
\hline A-I-28 & 8 & good & - & - & 3 & $\begin{array}{l}\text { very } \\
\text { good }\end{array}$ & 2 & $\begin{array}{l}\text { very } \\
\text { good }\end{array}$ \\
\hline A-II-2 & 4 & $\begin{array}{l}\text { very } \\
\text { good }\end{array}$ & - & - & - & good & 17 & good \\
\hline A-0-1 & 5 & good & - & - & 13 & good & 21 & good \\
\hline
\end{tabular}

- not detected.

\section{Identification of bacterial and fungal microbiota}

Among the bacterial isolates collected, the most numerous were Gram-positive cocci (16 isolates), then Gram-positive rod-shaped bacteria (5 isolates) and, finally, Gram-negative rod-shaped bacteria (6 isolates). The most dominant were bacterial species from the genera: Micrococcus, Staphylococcus, Bacillus, Corynebacterium, Flavobacterium, Pseudomonas (Fig. 1).

Quality characteristics of mycobiota isolated from the air in faculty's rooms showed dominating contributions of the genera: Aspergillus (13 isolates), Cladosporium (4 isolates), Penicillium (2 isolates), Fusarium (2 isolates), Candida (2 isolates), Botrytis (1 isolate), and Trichoderma (1 isolate) (Fig. 2). The genus Aspergillus has contained four identified species, A. fumigatus, A. flavus, A. versicolor and A. niger, the genus Cladosporium, two identified species $C$. cladosporioides and $C$. spaerospermum, the genus Penicillium with one identified species, $P$. expansum and the genus Fusarium with two identified species, $F$. oxysporum and F. solani.

In addition to the total number of microorganisms, the identification of isolated air microbiota is important for estimation of air quality and potential risk to public health because of eventually detection of some pathogenic microorganisms. This research showed that the taxonomic profile of the air microbiota isolated from faculty's rooms consisted of humanassociated and environmental taxa. It was observed that Gram-positive bacteria were more abundant. They possess better adaptation (thick cell walls, spores) and tolerance to dehydra- 
tion and adverse environmental conditions than Gram-negative bacteria. The most isolated bacteria were Gram-positive cocci (Micrococcus, Staphylococcus), which are, generally, associated to human skin and mucosa, thereby suggesting that the main bacterial contamination suspended in the indoor air derives from human presence. The other isolates were from genus Bacillus originated from environmental habitats (soils).

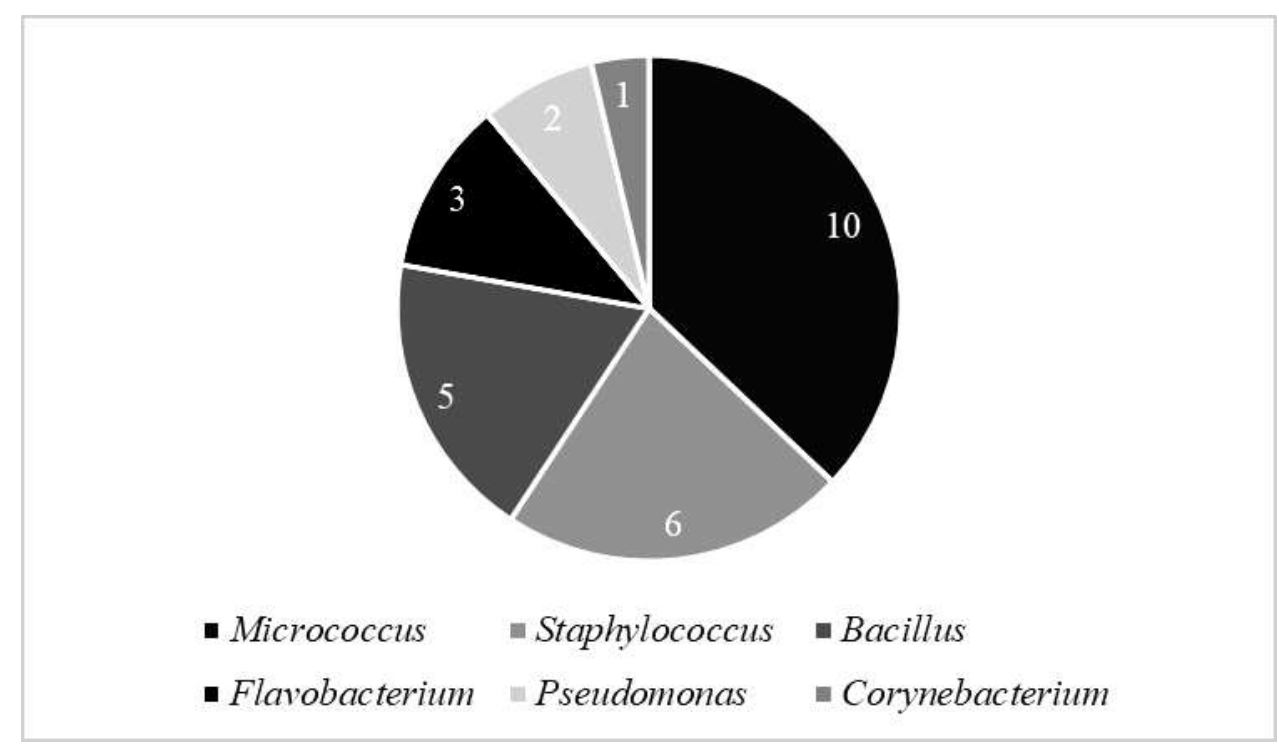

Figure 1. The isolated genera of bacteria and the number of strains.

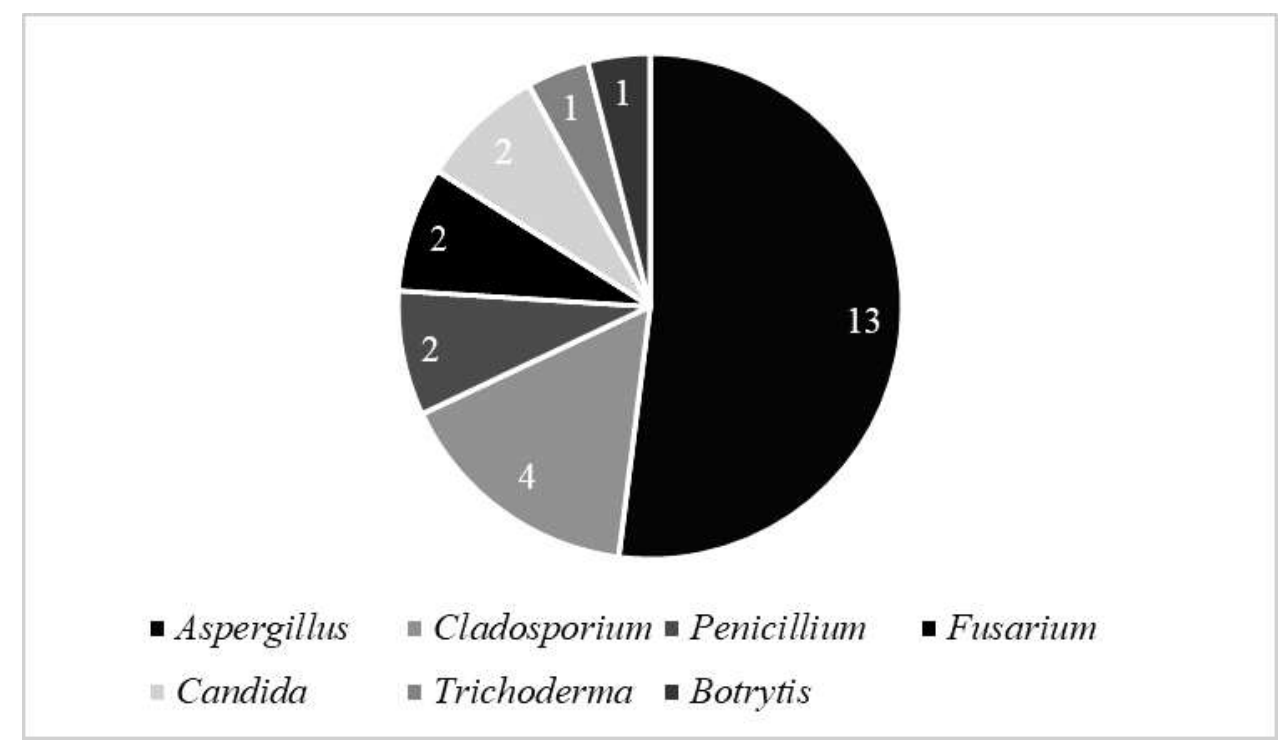

Figure 2. The isolated genera of fungi and the number of strains.

The isolated fungi were from genera Aspergillus, Penicillium, as well as so-called "outdoor mold" Cladosporium, Alternaria, Trichoderma, Botrytis. Moreover, the yeast Candida, habitant of human skin, hair, and nails was also detected. Species from the genera Aspergillus, Cladosporium, Penicillium, Trichoderma, Alternaria are recognized as species which, in increased concentrations, may contribute to the respiratory problems for asthmatic patients or patients with allergies (SHARPE et al., 2015).

The mentioned genera of bacteria and fungi have been shown to be among the most common microorganisms often isolated from the indoor air (GóRNY and DUTKIEWICZ, 2002; 
STRYJAKOWSKA-SEKULSKA et al., 2007; GUAN et al., 2015; SAVKOVIĆ et al., 2021). Owing to sequencing technology, in the last several years, more detailed information of indoor air microbiota is available. HewITT et al. (2012) have, also, concluded that a primary source of the bacteria present in the indoor air was the human body and the microbiota which inhabit the skin, oral cavity, mucous membrane of the nose. So that the isolated species of the genera Streptococcus, Corynebacterium, Flavimonas, Lactobacillus, Prevotella, Neisseria, Pseudomonas, Actinomyces are common. Also, the authors have found the species which are associated with the digestive tract of human Bacteroidetes, Lactobacillus, and members of the Enterobacteriaceae. Most bacteria were commensals and healthy people do not pose a health problem. The second source of bacteria in the air was the environment itself and thus were in the air present, and species of the genera Bacillus, Bradyrhizobium, Planomicrobium, Planococcus and members of the Microbacteriaceae. In addition, more diverse mycobiota was observed by PCR and clone library sequencing (PITKÄRANTA et al., 2005). The authors detected yeasts from genera: Malassezia, Candida, Cryptococcus, and Rhodotorula, especially in winter samples, as well as filamentous fungi from genera: Cladosporium, Penicillium, Acremonium, Aspergillus, Fusarium, Mucor, Trichoderma, Chetomium, Alternaria, Leptosphaerulina, Macrophoma, Ustilago, and yeast-like fungi Aureobasidium, Filobasidium, Rhodosporidium.

In this study, the microbiological quality of the air in the lecture rooms and reading room of the Faculty of Science, Kragujevac, Serbia was evaluated. As parameters of quality, the total number of bacteria/fungi and identification of collected isolates were determined. The breakpoints recommended by the American Industrial Hygiene Association (AIHA) for fungi in indoor air of business building, the Commission of the European Communities (CEC) for bacteria and the IMA index (indicate the number of opportunistic pathogenic bacteria) were used as breakpoints for evaluation of air quality (WANNER and GRAVESEN, 1993, HUNG et al., 2005; STRYJAKOWSKA-SEKULSKA et al., 2007).

The CEC recommendations, regarding the total number of bacteria, define several levels of bacteriological air contamination: 1-499 cfu/m $/ \mathrm{m}^{3}-$ low level, 500-999 $\mathrm{cfu} / \mathrm{m}^{3}-$ medium level, $>1.000 \mathrm{cfu} / \mathrm{m}^{3}-$ high level, and $>2.000 \mathrm{cfu} / \mathrm{m}^{3}$ - very high level. Appling these breakpoints, during the sampling months, the April and the May, medium to very high level of bacterial air contaminations was noticed. According to determined IMA index, very good to fair level of air quality was detected during sampling period. The IMA index is a valuable parameter which defines different levels of contamination in places at different biorisk. For example, hospital operation rooms, with very high risk, should have a maximum IMA value of 5. In this study, the IMA values were in the range $1-44$. This parameter, also, confirmed the fair air quality in April and May.

Regarding the total number of fungi, the AIHA has recommended that the number of fungal spores in business buildings should be less than $250 \mathrm{cfu} / \mathrm{m}^{3}$. If we use this breakpoint and compare with results of this study, the students, especially in May, were exposed to a higher concentration of fungi.

The obtain results confirm the importance of regular monitoring of microbiological quality of air in educational buildings. As it can be seen, the students have been exposed to higher concentration of bacteria and fungi, in particular periods. Many factors affect microbiological indoor air quality. These factors include poor ventilation, problems controlling temperature, high or low humidity, the number, and activities of occupants. Accordingly, frequent natural ventilation, decrease of humidity and adequate hygiene represents the primary procedures for safe environment. 


\section{References:}

[1] Andualem, Z., Gizaw, Z., Bogale, L., Dagne, H. (2019): Indoor bacterial load and its correlation to physical indoor air quality parameters in public primary schools. Multidisciplinary Respiratory Medicine 14: 2. doi: 10.1186/s40248-018-0167-y

[2] Basiñska, M., MichalkJewicz, M., RatajczaK, K. (2019): Impact of physical and microbiological parameters on proper indoor air quality in nursery. Environment International 132: 10509813. doi: 10.1016/j.envint.2019.105098

[3] Barnett, H.L., Hunter, B.B. (1998): Illustrated genera of imperfect fungi. 4th ed. American Phytopathological Society: 216 pp

[4] Bouillard, L., Michel, O., Dramaix, M., Devleeschouwer, M. (2005): Bacterial contamination of indoor air, surfaces, and settled the dust, and related dust endotoxin concentrations in healthy office buildings. Annals of Agricultural and Environmental Medicine 12 (2): 187-192.

[5] Brągoszewska, E., Mainka, A., Pastuszka, J.S., Lizończyk, K., Desta, Y.G. (2018): Assessment of bacterial aerosol in a preschool, primary school and high school in Poland. Atmosphere 9: 87. doi:10.3390/atmos9030087

[6] Borrego, S., Guiamet, P., Gómez de Saravia, S., Batistini, P., Garcia, M., Lavin, P., Perdomo, I. (2010): The quality of air at archives and the biodeterioration of photographs. International Biodeterioration \& Biodegradation 64 (2): 139-145. doi: 10.1016/j.ibiod.2009.12.005

[7] Douwes, J., Thorne, P., Pearce, N., Heederik, D. (2003): Bioaerosol health effects and exposure assessment: progress and prospects. Annals of Occupational Hygiene 47: 187-200. doi: 10.1093/annhyg/meg032

[8] JaAKKOla, J.J.K., Hwang, B.F., JaAKKola, M.S. (2010): Home dampness and molds as determinants of allergic rhinitis in childhood: a 6-year, population-based cohort study. American Journal of Epidemiology 172 (4): 451-459. doi: 10.1093/aje/kwq110

[9] HaAs, D., Galler, H., LuXner, J., Zarfel, G., Buzina, W., Friedl, H., Marth, E., HABIB, J., REINTHALER, F.F. (2013): The concentrations of culturable microorganisms in relation to the particulate matter in urban air. Atmospheric Environment 65: 215-222. doi: 10.1016/j.atmosenv.2012.10.031

[10] Hayleeyesus, S.F., Manaye, A.M. (2014): Microbiological quality of indoor air in university libraries. Asian Pacific Journal of Tropical Biomedicine 4 (1): S312-S317. doi: 10.12980/APJTB.4.2014C807

[11] Hewitt, K.M., Gerba, G.P., Maxwell, S.L., Kelley, S.T. (2012): Office space bacterial abundance and diversity in three Metropolitan areas. Plos One 7: e37849. doi: 10.1371/journal.pone.0037849

[12] Heederik, D., Von Mutius, E. (2012): Does diversity of environmental microbial exposure matter for the occurrence of allergy and asthma? Journal of Allergy and Clinical Immunology 130: 44-50. doi: 10.1016/j.jaci.2012.01.067

[13] Holt, J.G., Kreig, N.R., Sneath, P.H.A., Staley, J.T., Williams, S.T. (1994): Bergey's manual of determinative bacteriology. 9th ed. Williams \& Wilkins Press: 500 pp.

[14] Hung, L.L., Miller J.D., Dillon H.K. (2005): Field guide for the determination of biological contaminates in environmental samples. American Industrial Hygiene Association: $267 \mathrm{pp}$. 
[15] GóRNY, R.L., DutKIEWICZ, J. (2002): Bacterial and fungal aerosols in indoor environment in central and eastern European countries. Annals of Agricultural and Environmental Medicine 9 (1): 17-23.

[16] Guan, D., Guo, C., LI, Y., Lv, H., Yu, X. (2015): Study on the concentration and distribution of the airborne bacteria in indoor air in the lecture theatres at Tianjin Chengjian University. Procedia Engineering 121: 33-36.

doi: 10.1016/j.proeng.2015.08.1015

[17] Karvala, K., Toskala, E., LuUkKonen, R., Lappalainen, S., Uitti, J., Nordman, H. (2010): New-onset adult asthma in relation to damp and moldy workplaces. International Archives of Occupational and Environmental Health 83 (8): 855-865. doi: 10.1007/s00420-010-0507-5

[18] Napoli, C., Marcotrigiano, V., Montagna, M.T. (2012): Air sampling procedures to evaluate microbial contamination: a comparison between active and passive methods in operating theatres. BMC Public Health 12: 594. doi: 10.1186/1471-2458-12-594

[19] Nevalainen, A., Täubel, M., Hyvärinen, A. (2015): Indoor fungi: companions and contaminants. Indoor Air 25 (2): 125-156. doi: 10.1111/ina.12182

[20] Pasquarella, C., Pitzurra, O., Savino, A. (2000): The index of microbial air contamination. Journal of Hospital Infection 46 (4): 241-256.

doi: 10.1053/jhin.2000.0820

[21] Pitkäranta, M., Meklin, T., Hyvärinen, A., Paulin, L., Auvinen, P., Nevalainen, A., Rintala, H. (2008): Analysis of fungal flora in indoor dust by ribosomal DNA sequence analysis, quantitative PCR, and culture. Applied Environment and Microbiology 74 (1): 233-244. doi: 10.1128/AEM.00692-07

[22] Savković, Ž., Stupar, M., Unković, N., Ivanović, Ž., Blagojević, J., Popović, S., VuKoJEVIĆ, J., LJALJEVIĆ-GrBiĆ, M. (2021): Diversity and seasonal dynamics of culturable airborne fungi in a cultural heritage conservation facility. International Biodeterioration \& Biodegradation 157: 105163. doi: 10.1016/j.ibiod.2020.105163

[23] Stryjakowska-Sekulska, M., Piotraszewska-Pająk, A., SzyszKa, A., Nowicki, M., FILIPIAK, M. (2007): Microbiological quality of indoor air in university rooms. Polish Journal of Environment 16: 623-632.

[24] Sharpe, R.A., Bearman, N., Thornton, C.R., Husk, K., Osborne, N.J. (2015): Indoor fungal diversity and asthma: a meta-analysis and systematic review of risk factors. Journal of Allergy and Clinical Immunology 135 (1): 110-122. doi: 10.1016/j.jaci.2014.07.002

[25] TSAI, F.C., MASHER, J.M. (2005): Concentrations of airborne culturable bacteria in 100 large US office buildings from the BASE study. Indoor Air 15: 71-81. doi: 10.1111/j.1600-0668.2005.00346.x

[26] Wanner, H.U., Gravesen S. (1993): Biological particles in indoor environment: European Collaborative Action. Indoor Air Quality \& Its Impact on Men. Report No.12. Commission of the European Communities, Directorate General for Science, Research and Development. Joint Research Institute - Environment Institute, Luxemburg.

[27] https://www.euro.who.int/_data/assets/pdf_file/0017/43325/E92645.pdf?ua=1 Accessed October $20^{\text {th }}, 2020$. 